\title{
The Effect of Civil Servants' Mobbing Perception on Organizational commitment: A Practice in Special Provincial Administration of Erzurum
}

\author{
Esra Kızıloğlu \\ Selçuk University of Faculty of Economics and Administration Sciences \\ Email: esraciftci@selcuk.edu.tr \\ Aykut Bedük \\ Selçuk University of Faculty of Economics and Administration Sciences \\ Email:abeduk@hotmail.com
}

\section{Doi:10.5901/mjss.2015.v6n4p144}

\section{Abstract}

Mobbing which is workers' worst nightmare causes not only physical and psychological damage, but also various costs in terms of organizations. The most important cost of them are decreasing organizational commitment of the employers and consequently, increasing rate of quitting the job. The main purpose of this study is toobserve the effects of the mobbing civil servants are exposed to at the workplace on their commitment to their organizations. With these purposes, the connection between being exposed to mobbing and organizational commitment of employees working in Special Province Administration of Erzurum has been examined. In the analyses, it has been reached that civil servants have been rarely exposed to mobbing and that their commitment to their organizations are at moderate level. Besides, as a result of analysis it has been reached that there is a negative relation between variables and to explain the organizational commitment variable, mobbing variable is statistically meaningful.

Keywords: Mobbing, Bullying, Organizational Commitment, Affective Commitmen, Normative Commitment, Continuation Commitment

\section{Conceptual Framework}

\subsection{Mobbing}

In recent years, violent behaviors have been reported increasingly in countries, such as Austria, Australia, Denmark, Sweden, England and USA (Chappell and Martino, 2006: 21-22). These behaviors, originally thought to be associated with psychological stress from competition that exists in the workplace, but the presence and the importance of its size hasn't been noticed before and are frequently seen especially among the employees who quit their jobs by resigning, are called "mobbing" (Tınaz, 2006: 11).

Mobbing is typically psychological abuses which are committed by a group of employees towards an employee. Mobbing contains of repeated behaviors like using negative words towards someone, criticizing, spreading gossips and wrong information about someone in order to isolate him/her from social relationships, making fun of someone (Chappell and Martino, 2006: 21-22). These continuous and repeated behaviors causes a challenging duration to an individual. It has some conclusions which affect him/her by both physically and psychologically like disinclining him/her from work, stress, terrorization, harassment, unhappiness, insomnia and various health problems.

Mobbing, as a concept, is originated from the English word "mob" which means gathering somewhere, attacking and disturbing (Einarsenetaş, 2011: 4; Eser, 2009:1). The origin of the word is derived from the words "mobile vulgus" which means "unstable crowd" in Latin (Tutar, 2004: 102). Although the mobbing term has been common thanks to Leymann, the term was first used by Etholog Konrad Lorenz of Australia $(1963,1965,1968)$ in order to describe animals' behaviors. In the meantime, Peter-Paul Heinemann of Sweden used mobbing term to define the aggressive behaviors among the students at school (Duffy and Sperry, 2012: 24). In business life, mobbing was first used by Leymann who suggested the term during his studies in Sweden in early 1980s. After these studies in Sweden, Leymann draw public's attention to mobbing in Germany and specified the importance of the point (Poussard and Çamuroğlu, 2009: 3; Aygün, 2012: 94).

Mobbing subject became a common point in all disciplines with the studies which was conducted by Leymann in 1980 and which are accepted as basic (Duffy and Sperry, 2012: 23). According to Leymann, mobbing is a terror and a systematic process which is conducted by one or several people towards an individual who is targeted with hostile and unethical ways. With mobbing, an individual is abandoned vulnerably and despairingly (Leymann, 1990: 120; Leymann, 1996: 168). There is no big difference between a normal conflict and mobbing. What makes them different is mobbing behaviors are repeated and has continuity (Salin, 2003: 1215). 
After all these definitions, to make general definition it can be said: "Mobbing is kind of behaviors exhibited consciously by one or more persons with the purpose of alienating and precluding the victim from workplace which are all kinds of damaging to the personality, constant and repeated negative physical and social (connotation, mockery, gossip, disdain et al.) behaviors." As a result of these behaviors, physical and psychological balance of the individual is spoilt and his/her working life goes into danger since it affects his/her performance.

Leymann has identified 45 different mobbing behaviors about this subject. Later, he classified these behaviors into five categories. These are (Leymann, 1996: 170): 1. Attacks which block individual from expressing himself/herself (being interfered and being criticized constantly); 2. Attacks to social relationships (people around you not talking to you); 3 . Attacks on individual's social reputation (being exposed to ridiculous situations, people's poor speech about you); 4 . Attacks on individual's life and wok quality (being given meaningless jobs, constant duty shifts); 5 . Direct attacks on health (threatening with physical violence, sexual harassment).

\subsection{Organizational Commitment}

When the commitment types in working life has been studied, organizational commitment is the subject which is most studied in both domestic and international studies. Important results which were brought out by organizational commitment and the positive effects on employees have been found valuable and consequently have been paid great attention by academic community (Çiftçi, 2013: 49).

Commitment, as a concept and way of understanding, exists everyplace where there is community emotion and is a way of explaining the social instinct (Balay, 2000: 14). Turkish Language Society has defined commitment "Feeling or showing intimacy with love, respect towards someone" (TDK, www.tdk.gov.tr). Organizational commitment, which means employees' psychological situation which reflects their commitment to the organization they work for, has become an important point for the organizations since people management is hard and complicated and affects organization administration (Güçlü, 2006: 5-6).

Organizational commitment, in short, is employee's showing commitment to organization, feeling a strong relationship with the organization which means his/her psychological identification with the organization (Çiftçi, 2013: 46). According to Steers (1977) employee feels himself/herself strong and as a family member thanks to organization commitment (Steers, 1977: 46). Organizational commitment is defined as employee's internalizing the features and perspective of the organization (O'Reilly and Chatman, 1986: 493). Salancik defines organizational commitment like this: "it is behavioral acts which emerges as a result of individuals' commitment attitudes" (Reichers, 1985: 468). Winer (1982) explains organizational commitment as sum of the internalized stress in order to act to meet the organizational benefits (Winer, 1982: 418).

With organizational commitment, employee feels himself/herself responsible to achieve the goals without expecting no return from institution by internalizing the value judgment and the goals (Akt. Yıldız et al, 2013: 90). Organizational commitment is characterized with 3 important items. These are (Steers, 1977: 46) a strong belief in the organization's purposes and values and adopting them, individual's trying harder than the organization expects and the strong will which feels to sustain his/her membership.

The most important contribution to organizational commitment studies was done by Allen and Meyer. Allen and Meyer see the organizational commitment as a psychological situation which binds the individual his/her organization and classify the organizational commitment affective, continuation and normative (Allen and Meyer, 1990: 3, Meyer and Allen, 1991, Güçlü, 2006: 11). Affective commitment is a kind of commitment which connects employees to organizations emotionally and makes them happy since they are members of the organization (Weiner, 1983: 423-424, Allen and Meyer, 1990: 2). In Affective Commitment, employee shares some values with the organization and this commitment is open to influence by personality, job features and experiences (Karasoy, 2011: 56). Continuation commitment develops as a result of employees' investments on their organizations. In this commitment, employee thinks that he/she has spent his time and effort enormously, has done investments and consequently he/she is obliged to stay in the organization. A person who is commitment to his/her organization permanently has the idea that if he/she quits organizations, he/she has less options. While some of these people stay in the organization since they cannot find another job, some stay because of some challenging reasons like health and family problems $(2006,133)$. Normative Commitment reflects responsibility emotions about the employees' staying in the organization. The reason why employees' are loyal to their organizations isn't because they are asked to behave like this for their personal benefits but they believe what they do is right and ethic (Balay, 2000: 22).

\section{The Relation between Mobbing and Organizational Commitment}

A negative relation between mobbing behaviors which alienate and preclude the employee from organization which he/she works and organizational commitment which makes him/her identify with the organization is expected. When we 
look into the researches which were made to detect the relation between mobbing and organizational commitment in our country, it is seen that mostly a negative relation between these two variables has been found.

Mobbing behaviors at the workplaces prevent employees from working, alienate them both from workplace and their social life as a result of tedious, humiliating and unethical behaviors. Employees being exposed to mobbing behaviors not only have emotional and physical problems (depression, fear, sleeping disorders, anxiety, despair, panic attack, et al) but also have some manners and behaviors towards their organizations they work for. The cost of these manners and behaviors to the enterprise cannot be ignored. Several problems like working in low performance, inefficiency, absenteeism, quitting job, lack of satisfaction, organizational disloyalty, not trusting in the organization and consequently declining of the organizational commitment are unwanted situations for both organizations and individuals.

Studies conducted by Division of Workplace Health and Safety (1998), Namie and Namie (2000), Office of the Employee Ombudsman (2000), Queensland Workplace Bullying Taskforce (2001), Randall (1997) and Thomson (1997) have showed that mobbing eats away employees' commitment and causes a reduction of their commitment to the organization (Akt. Özler et al, 2008: 10).

\section{Research Methodology}

The main purpose of the study is to analyze the relation between the situation in which employees are exposed to mobbing and their organizational commitment.

Research universe consists of the employees working in Special Provincial Administration of Erzurum. According to the information which was obtained in the research date, there are about 639 employees in the institution. Some of these employees work in the center and some of them in the counties. Samples have been taken because opportunity to reach the whole universe is limited by time, accessibility and cost facts. As research sample, random/casual sample technique was chosen in parallel to the number of the employees; for this purpose, 350 surveys have been delivered to the employees. 210 of these have been collected and for some reasons (lacking, incorrect filling et al) 204 of them have been evaluated.

Research data was gathered by survey technique. The survey consists of three chapters; demographic information, mobbing and organizational commitment. The survey was created by scanning national and international literature and integrating the scales which are appropriate to the purpose and the importance of the study. Designated survey mass was carried out by face to face survey method as part of privacy policy.

In order to evaluate whether the employees were exposed to mobbing, "Psychological Violence Behaviors in the Workplace (PVBW)" scale, which was developed by Yıldırım and Yıldırım and consisted of 33 items, was used. This scale is analyzed under four main topics: Isolation of the individuals from work, to attack vocational status, to attack personality and direct negative behaviors. To define frequency of the behaviors, 5 Likert method was used: $1=$ never, $5=$ always. In the second scale, to evaluate organizational commitment of the employees, 3-dimensioned "Organizational Commitment Scale", which was developed by Meyer, Allen and Smith. Questions was formed within 5 Likert method; $1=$ Totally disagree and 5= Totally agree. Data was analyzed with SPSS program.

\subsection{Statistical Analyses and Findings}

Scales used in the study was separated by their dimensions and every dimension's reliability was tested by calculating the Cronbach Alpha value

Table 1. Reliability of the Survey by its Dimensions

\begin{tabular}{|l|c|c|l|c|c|}
\hline Variables & $\begin{array}{c}\text { Number of } \\
\text { Questions }\end{array}$ & $\begin{array}{c}\text { Cronbach } \\
\text { Alpha }\end{array}$ & Variables & $\begin{array}{c}\text { Number of } \\
\text { Questions }\end{array}$ & $\begin{array}{c}\text { Cronbach } \\
\text { Alpha }\end{array}$ \\
\hline Mobbing Scale & 33 & 0,941 & $\begin{array}{l}\text { Organizational } \\
\text { Commitment Scale }\end{array}$ & 26 & 0,875 \\
\hline Isolation of the employees from work & 11 & 0,811 & Affective Commitment & 8 & 0,878 \\
\hline Attacking vocational status & 9 & 0,866 & $\begin{array}{l}\text { Continuation } \\
\text { Commitment }\end{array}$ & 8 & 0,647 \\
\hline Attacking personality & 9 & 0,897 & Normative Commitment & 10 & 0,798 \\
\hline Direct negative behaviors & 4 & 0,931 & & & \\
\hline
\end{tabular}

As seen on Table 1, Cronbach Alpha coefficients (a) of the used scales are 0,941 in mobbing and 0,875 in organizational commitment. It is understood from these results that scales are highly reliable $(\alpha>0,70)$.

The findings related to the demographic variables of the study are on the following table 
Table 2. Demographic Characteristics of Participants

\begin{tabular}{|c|c|c|c|c|c|c|c|}
\hline DemographicValues & Sub-characteristics & $\mathbf{N}$ & $\%$ & DemographicValues & Sub-characteristics & $\mathbf{N}$ & $\%$ \\
\hline \multirow[t]{3}{*}{ Gender } & Male & 173 & 84,8 & \multirow[t]{3}{*}{ Position } & Regular employee & 184 & 90,2 \\
\hline & \multirow{2}{*}{ Female } & \multirow{2}{*}{31} & \multirow{2}{*}{15,2} & & Contractual employee & 9 & 4,4 \\
\hline & & & & & Seasonal employee & 11 & 5,4 \\
\hline \multirow[t]{5}{*}{ Age } & Younger than 25 & 3 & 1,5 & \multirow{5}{*}{ Working time in the institution } & Less than 6 monhts & 10 & 4,9 \\
\hline & $25-35$ & 40 & 19,6 & & 6 months - 1 year & 4 & 2,0 \\
\hline & $36-40$ & 27 & 13,2 & & $1-5$ years & 38 & 18,6 \\
\hline & $41-50$ & 85 & 41,7 & & 6-10 years & 50 & 24,5 \\
\hline & Older than 50 & 49 & 24,0 & & More than 10 years & 102 & 50,0 \\
\hline \multirow[t]{2}{*}{ MaritalStatus } & Married & 171 & 83,8 & \multirow{5}{*}{ Seniority at profession } & Less than 6 months & 6 & 2,9 \\
\hline & Single & 33 & 16,2 & & 6 months - 1 year & 2 & 1,0 \\
\hline \multirow[t]{5}{*}{ Educational Level } & Primary education & 37 & 18,1 & & $1-5$ years & 36 & 17,6 \\
\hline & High School & 83 & 40,7 & & 6-10 years & 38 & 18,6 \\
\hline & Associate degree & 24 & 11,8 & & More than 10 years & 122 & 59,8 \\
\hline & Bachelor's degree & 34 & 16,7 & & & & \\
\hline & Undergraduate & 26 & 12,7 & & & & \\
\hline
\end{tabular}

On the survey, participants were asked "Have you ever been exposed to mobbing in the workplace?" and according to their answers ( $1=$ yes, $2=$ no, $3=$ not sure), their exposure to mobbing cases was shown on the Table 3.

Table 3. Participants' Exposure to Mobbing Cases

\begin{tabular}{|c|c|c|}
\hline Expressions & Number & $\%$ \\
\hline Yes & 26 & 12,7 \\
\hline No & 144 & 70,6 \\
\hline Not sure & 34 & 16,7 \\
\hline Total & 204 & 100 \\
\hline
\end{tabular}

To the question whether they were ever exposed to mobbing, $\% 70,6$ of the participants said they weren't $\% 12,7$ said they were exposed and \%16,7 said they aren't sure in their answers. In other words, most of the participants (114) believe that they weren't exposed to mobbing behaviors.

\subsubsection{Findings On Participants' Mobbing, Organizational Commitment and Sub-Dimension Levels}

Average and standard deviation levels on the participants' mobbing, organizational commitment and sub-dimensions are shown on the Table 4.

Table 4. Descriptive Statistics on Mobbing and Organizational Commitment Dimensions

\begin{tabular}{|c|c|c|c|c|c|c|c|}
\hline Expressions & ஓे & 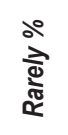 & : & 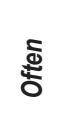 & 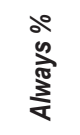 & 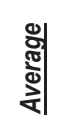 & 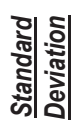 \\
\hline Mobbing Scale & 29,4 & 50,5 & 18,6 & 1,5 & 0 & 1,95 & 0,648 \\
\hline Isolation of the individual from work & 20,1 & 50,0 & 27,9 & 2,0 & 0 & 2,13 & 0,683 \\
\hline Attacking on vocational status & 27,0 & 45,6 & 24,5 & 1,5 & 1,5 & 2,08 & 0,764 \\
\hline Attacking on personality & 48,0 & 37,7 & 12,3 & 1,0 & 1,5 & 1,73 & 0,739 \\
\hline Direct NegativeBehaviors & 53,9 & 28,9 & 9,3 & 1,5 & 6,4 & 1,70 & 1,042 \\
\hline Expressions & 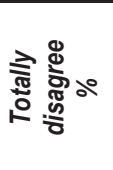 & 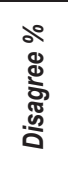 & 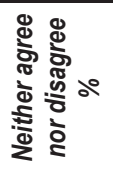 & 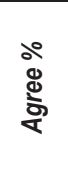 & ॠँّ & 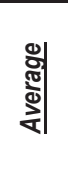 & 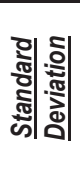 \\
\hline Mobbing Scale & 1,5 & 7,4 & 57,4 & 32,8 & 1,0 & 3,19 & 0,594 \\
\hline Affective Commitment & 4,9 & 16,2 & 33,3 & 38,2 & 7,4 & 3,22 & 0,958 \\
\hline Continuation Commitment & 2,5 & 8,3 & 57,8 & 29,4 & 2,0 & 3,13 & 0,656 \\
\hline NormativeCommitment & 1,0 & 8,8 & 53,9 & 33,8 & 2,5 & 3,22 & 0,662 \\
\hline
\end{tabular}


When the table below analyzed, it is found out that are of participants' exposure to mobbing expressions is 1,95 . Responders generally answered the mobbing scale rarely $(\% 50,5)$ which means they believe that they were slightly exposed to mobbing.

According to the table, the average agreement of organizational commitment was found by 3,19 . Responders, as general, answered the organizational commitment scale neither agree nor disagree $(\% 57,4)$. According to this finding, it can be said that participants have an average organizational commitment level. If we look into the mobbing scale in terms of dimensions;

\subsubsection{Correlation Analysis}

The correlation analysis which was done in order to measure the relation between free and dependent variables is shown on the following table. According to this, there is a weak negative relation $(r:-0,264)$ between mobbing and organizational commitment. So, $\mathrm{H}_{1}$ hypothesis is accepted. $\left(\mathrm{H}_{1}\right.$ : there is statistically meaningful and opposite directional relation between the employees' mobbing perception and organizational commitment)

Table 5. The Relation between Mobbing and Organizational Commitment

\begin{tabular}{|c|c|c|c|c|c|c|c|c|c|}
\hline & 1 & 2 & 3 & 4 & 5 & 6 & 7 & 8 & 9 \\
\hline 1. Isolation of the individual from work & 1 & & & & & & & & \\
\hline 2. Attacking on vocational status & $0,553^{* *}$ & 1 & & & & & & & \\
\hline 3. Attacking on personality & $0,549^{* *}$ & $0,539^{* *}$ & 1 & & & & & & \\
\hline 4.Direct Negative Behaviors & $0,491^{* *}$ & $0,394^{* *}$ & $0,760^{* *}$ & 1 & & & & & \\
\hline 5. Mobbing Scale & $0,772^{* *}$ & $0,703^{* *}$ & $0,785^{\star \star}$ & $0,715^{* *}$ & 1 & & & & \\
\hline 6. Emotional Commitment & $-0,220^{* *}$ & $-0,028$ & $-0,383^{* *}$ & $-0,316^{* *}$ & $-0,285^{\star *}$ & 1 & & & \\
\hline 7. Continuation Commitment & $-0,110$ & $-0,220^{* *}$ & 0,063 & $0,144^{*}$ & $-0,073$ & $0,383^{* *}$ & 1 & & \\
\hline 8.NormativeCommitment & $-0,169^{*}$ & $-0,132$ & $-0,161^{*}$ & $-0,122$ & $-0,159^{*}$ & $0,349^{*}$ & $0,290^{* *}$ & 1 & \\
\hline 9. Organizational Commitment & $-0,229^{* *}$ & $-0,189^{* *}$ & $-0,262^{* *}$ & $-0,159^{*}$ & $-0,264^{* *}$ & $0,727^{* *}$ & $0,587^{* *}$ & $0,658^{* *}$ & 1 \\
\hline
\end{tabular}

\subsubsection{Regression Analysis}

Regression analysis which were made to test the $\mathrm{H}_{2}$ hypothesis are shown on the following table.

Table 6. Regression Analysis between Mobbing and Organizational Commitment

\begin{tabular}{|c|c|c|c|c|c|}
\hline \multicolumn{6}{|c|}{ Model Abstract } \\
\hline $\mathbf{R}$ & R Square & \multicolumn{2}{|c|}{ Corrected R Square } & \multicolumn{2}{|c|}{ StandardErrors of the outputs } \\
\hline 0,26 & 0,07 & 0,07 & & \multicolumn{2}{|c|}{$\frac{\text { IErrors of the outputs }}{0,64}$} \\
\hline \multicolumn{6}{|c|}{ ANOVA } \\
\hline & Sum of squares & df & Average squares & $\mathbf{F}$ & $\mathbf{P}$ \\
\hline Regression & 6,25 & 1 & 6,25 & 15,13 & 0,00 \\
\hline Residual & 83,49 & 202 & 0,41 & & \\
\hline Total & 89,75 & 203 & & & \\
\hline
\end{tabular}

According to the table below, $\% 7$ of the organizational commitment variable can be explained with mobbing variable. If Anova table is analyzed, $\mathrm{H}_{2}$ hypothesis is accepted since $\mathrm{F}$ values is 15,13 and $p$ value is $0,00 .\left(\mathrm{H}_{2}\right.$ : mobbing variable is statistically meaningful in explaining the organizational loyalty variable.). According to this, the generated regression analysis is meaningful which means it is statistically possible to guess the mobbing variable with organizational commitment variable.

\section{Conlusion}

Mobbing which has become a nightmare for employees is now accepted as a human rights violation all over the world. It is a necessity for both government and enterprises to take measures and stop mobbing, since it is harmful to individual himself/herself, his/her environment and the organization he/she work for. When we look into our country's mobbing report, especially in the public sector, an increase in the mobbing cases is seen. It was seen appropriate to make this study on the 
civil servants because of insufficiency in the research on the mobbing behaviors which civil servants are exposed to.

Consequently, it revealed that civil servants who answered the survey were slightly exposed to mobbing and their organizational commitment was at average level. In the correlation analysis which was made to locate the relation between mobbing and organizational commitment and its direction, a weak negative relation $(r:-0,264)$ among the variables. In the result of regression analysis, it was seen that \%7 of the organizational commitment variable can be explained with mobbing variable and mobbing variable is statistically meaningful in explaining organizational commitment variable.

Since mobbing is a sensitive topic and employees cannot express their feelings easily, it not only affects their answers to the mobbing questions but also can decrease their commitment and loyalty to their organizations. Whether private or public institution, every organization should stop mobbing behaviors in order to increase their employees' commitment, should warn who has mobbing behaviors and take the necessary measurements.

\section{References}

Allen, Natalie J. and Meyer, John P. (1990). The measurement and antecedents of affective, continuance and normative commitment to the organization. Journal Of Occupational Psychology, 63, 1-18.

Aygün, H. Ali (2012). Psikolojik Yıldırma (Mobbing) Üzerine Nitel Bir Araştırma. Gümüşhane Üniversitesi Sosyal Bilimler Elektronik Dergisi, 5, 92-121.

Balay, Refik (2000). Yönetici ve Öğretmenlerde Örgütsel Bağııık, Ankara: Nobel Yayın Dağıtım.

Bayram, Levent (2006). Yönetimde Yeni Bir Paradigma: Örgütsel Bağlılık, Sayıştay Dergisi, (59), 125-139.

Chappell, Duncan and Martino, Vittorio Di (2006). Violence at Work (3.baskı). Geneva: International Labour Office.

Çiftçi, Esra (2013). Genel Sinizmin ve Örgütsel Sinizmin Iş̧e Bağlıık Düzeyine Etkisi: Konya Illindeki Otel Çalışanları Üzerinde Bir Araştırma. Yayınlanmamış Yüksek Lisans Tezi, Selçuk Üniversitesi Sosyal Bilimler Enstitüsü, Konya.

Duffy, Maureen and Sperry, Len (2012). Mobbing: Causes, Consequences, and Solutions. Oxford University Press.

Einarsen, Stale, Hoel, Helge, Zapf, Dieter and Cooper, Cary L. (2011). Bullying and Harassment in the Workplace: Developments in Theory, Research, and Practice (2.baskı). Taylor and Francis Group, CRC Press.

Eser, Oktay (2009). Mobbing Kavramının Türkçe Serüveni (http://turkoloji.cu.edu.tr/YENI\%20TURK\%20DILI/oktay_eser_mobbing_ kavrami.pdf)

Güçlü, Hatice (2006). Turizm Sektöründe Durumsal Faktörlerin Örgütsel Bağlılık Üzerindeki Etkisi. Eskişehir: Anadolu Üniversitesi Yayınları.

Karasoy, H. Alpay (2011). Örgütsel Bağlıık. (Editör: Aykut Bedük). Örgüt Psikolojisi: Yeni Yaklaşımlar, Güncel Konular. Konya: Atlas Akademi, 49-57.

Leymann, Heinz (1990). Mobbing and Psychological Terror at Work Places. Violence and Victims. 5 (2), 119-126.

Leymann, Heinz (1996), The Content and Development of Mobbing at Work. Europen Journal of Work and Organizational Psychology, 5(2), 165-184.

Meyer, John P. and Allen, Natalie J. (1990). A Three-Component Conceptualization of Organizational Commitment. Human Resource Management Review, 1(1), 61-89.

O'Reilly, Charles and Chatman, Jennifer (1986). Organisational Commitment and Psychological Attachment: The Effects of Compliance, İdentification, and İnternalization on Prosocial Behavior. Journal Of Applied Psychology, 71(3), 492-499.

Özler, Derya E., Atalay, Ceren G. ve Şahin, Meltem D. (2008). Mobbing'in Örgütsel Bağlılık Üzerine Etkisini Belirlemeye Yönelik Bir Araşııma. Dumlupınar Üniversitesi Sosyal Bilimler Dergisi, 22, 37-60.

Poussard, Jale M. ve Çamuroğlu, Meltem İ. (2009). Psikolojik Taciz: İ̧̧erindeki Kabus. Ankara: Nobel Yayın Dağııım.

Reichers, E.Arnon (1985). A Review and Reconceptualization of Organizational Commitment. The Academy of Management Review 10 (3), 465-476.

Salin, Denise (2003). Ways of Explaining Workplace Bullying: A Review of Enabling, Motivating and Precipitating Structures and Processes in the Work Environment. Human Relations, 56 (10), 1213-1232.

Steers, Richard M. (1977). Antecedents and Outcomes of Organizational Commitment. Administrative Science Quarterly, 22 (1), $46-56$.

Tınaz, Pınar (2006). Mobbing: İşyerinde Psikolojik Taciz, Çalışma ve Toplum, 10, 11-22.

Tutar, Hasan (2004). İşyerinde Psikolojik Şiddet Sarmalı: Nedenleri ve Sonuçları, Yönetim Bilimleri Dergisi, 2 (2), 101-128.

Wiener, Yoash (1982) Commitment in Organization A Normative View, TheAcademy of Management Review, 7(3), 418-428.

Yıldırım, Dilek ve Yıldırım Aytolan (2010). Sağık Alanında Çalışan Akademisyenlerin Karşılaştıkları Psikolojik Şiddet Davranışları ve Bu Davranışların Etkileri. Türkiye Klinikleri J Med Sci, 30(2), 559-570.

Yıldız, Gültekin, Akbolat, Mahmut ve Işık, Oğuz (2013). Psikolojik Taciz Ve Örgütsel Bağlılık: Sağlık Çalışanları Üzerine Bir Araştırma. Manas Sosyal Araştırmalar Dergisi, 2 (6), 85-117.

Yildirim, Dilek and Yildirim, Aytolan (2008). Development and Psychometric Evaluation of Workplace Psychologically Violent Behaviours Instrument. Journal of Clinical Nursing, 17, 1361-1370.

TDK, www.tdk.gov.tr, Erişim Tarihi: 26.12.2013.

http://www.workplacebullying.org, Erişim Tarihi: 20.12.2013. 